\title{
УРОЖАЙНІСТЬ СУЧАСНИХ ГІБРИДІВ КУКУРУДЗИ ЗАЛЕЖНО ВІД ЗАСТОСУВАННЯ ЗАСОБІВ ЗАХИСТУ РОСЛИН ТА РЕГУЛЯТОРУ POCTY
}

Н. М. Музафаров, К. М. Манько, І. М. Музафаров

Інститут рослинництва ім. В. Я. Юр'єва НААН

Узагальнені дворічні (2009-2010 pр.) дослідження з вивчення реакції сучасних гібридів кукурудзи на застосування регулятору росту та засобів захисту рослин показали, що найбільша прибавка врожайності від обробки насіння фунгіцидом Віал ТТ і інсектицидом Табу відмічена у середньостиглого гібрида Кредит МВ на фоні обмеженого застосування добрив (гній 30 т/га $\left.+\mathrm{N}_{30} \mathrm{P}_{30} \mathrm{~K}_{30}\right)-0,71$ т/га. У досліді з вивчення реакції середньораннього гібриду Варта МВ на застосування регулятору росту рослин Гумата калію найбільша прибавка врожайності зерна отримана на фоні внесення повної дози добрив (гній 30 т/га $+\mathrm{N}_{60} \mathrm{P}_{60} \mathrm{~K}_{60}$ ) + обробка насіння + обприскування посіву у фазу 3-5 листа $-0,80$ т/га.

Урожайність, кукурудза, гібрид, хімічний захист рослин, фон живлення, регулятор росту рослин

У сільськогосподарському виробництві України кукурудзі надано важливе значення, у зерновому балансі відведена провідна роль. Вона $\epsilon$ надійною страховою культурою з високою урожайністю в роки несприятливі для врожайності озимих та ярих зернових культур. За допомогою кукурудзяного зернофуражу вирішуються основні проблеми збалансованої годівлі в галузі тваринництва. Зерно кукурудзи є цінною сировиною харчової та інших галузей переробної промисловості [1].

Кукурудза - одна з важливіших і найбільш урожайних сільськогосподарських культур. За врожайністю вона перевищує найбільш розповсюджені зернофуражні хліба і знаходить надзвичайно різнобічне використання: дає цінні харчові продукти для людини, кращі за різноманіттям та поживністю корми тваринам, представляє собою дешеву сировину для промисловості та особливо багате джерело вуглеводів. Ця культура майже не має відходів, тому що використовується зерно, листя, стебла, стрижні початків i навіть ii коріння. Цінні властивості кукурудзи перевірені протягом багатьох століть народами різних країн [1-4].

Потенційні можливості цієї культури використовуються лише на 3050 \%, а тому найближчими роками ії врожайність планують збільшувати за

(C) Н. М. Музафаров, К. М. Манько, І. М. Музафаров. 2012. ISSN 0582-5075. Селекція і насінництво. 2012. Випуск 102. 
рахунок стабілізації посівних площ та використання гібридів різних груп стиглості. Важливим резервом підвищення врожайності зерна кукурудзи $є$ також впровадження сучасних технологій, які можуть забезпечити використання найновіших досягнень селекції і насінництва, хімізації та механізації виробничих процесів на основі точного біологічного контролю за станом і розвитком рослин [5].

Застосування до цього часу інтенсивних технологій вирощування сільськогосподарських культур, які спрямовані на максимальне використання засобів механізації, мінеральних добрив та високоінтенсивних сортів i гібридів, безперечно, забезпечило зростання їх врожайності. Однак ці технології створені методом «необмеженої інтенсифікації» та ефективні лише за сприятливих умов вирощування. Але підвищення вартості паливномастильних матеріалів та агроресурсів до рівня світових цін призвело до значного збільшення їх частки в собівартості продукції. У сучасних умовах забезпечення функціонування АПК на застарілих технологічних принципах $\epsilon$ економічно недоцільним. У зв'язку зі створенням багатоукладного сільського господарства, а також виникненням певних агрокліматичних проблем назріла проблема розробки нових підходів до оптимізації й інтенсифікації технології вирощування сільськогосподарських культур [5].

Проблема забезпечення зерном кукурудзи в Україні має вирішуватися в кількох напрямках: шляхом нарощування виробництва зерна за рахунок підвищення врожайності гібридів, їх адаптивності до стресових факторів середовища, а також розширення посівних площ та застосування сучасних технологій вирощування з використанням менш затратних засобів хімізації (регуляторів росту та ін.).

Умови і методика проведення досліджень. Дослідження проводили в Інституті рослинництва ім. В. Я. Юр'єва НААН у 2009-2010 рр. в лабораторії рослинництва і сортовивчення у стаціонарній паро-зерно-просапній сівозміні, яка створена в 1972 році за багатофакторною схемою методом розщеплених ділянок. Схема внесення добрив включала: а) без добрив сівозмінний фон; б) сівозмінний фон +30 т/га гною; в) сівозмінний фон + 30 т/га гною $+\mathrm{N}_{30} \mathrm{P}_{30} \mathrm{~K}_{30}$, г) сівозмінний фон +30 т/га гною $+\mathrm{N}_{60} \mathrm{P}_{60} \mathrm{~K}_{60} . \mathrm{Y}$ дослідженнях застосували препарати: фунгіцид Віал ТT, інсектицид Табу та регулятор росту рослин Гумат калію в порівнянні з контролем без обробки.

Віал ТТ - комплексний фунгіцидний протруювач насіння зернових культур з антистресовими компонентами. Механізм дії: проникаючи в зернівку та переміщаючись до зародка насіння, препарат знищує сажкову інфекцію. Потім протруювач пересувається до точок зростання проростків. Введені до складу Віала ТТ антистресові компоненти в мікрокількостях містять біологічно активні рослинні модулятори. Вони виключають можливий ретардантний ефект, який інколи за несприятливих умов (наприклад, посуха, заглиблений посів насіння) можуть викликати тріазольні з'єднання, у тому числі тебуконазол. Віал ТТ укріплює імунітет рослин, підвищує схожість насіння, збільшує енергію проростання, забезпечує дружні сходи. 
Системний інсектицид Табу використовували для протруювання насіння кукурудзи з метою захисту сходів рослин від комплексу шкідників . Табу характеризується вираженою системною активністю, проникає в проростки і молоді рослини через листя і коріння. Він активно впливає на нервову систему шкідливих комах, блокуючи никотинергитичні рецептори постсинаптичного нерва. Препарат швидко пригнічує передачу сигналів через центральну нервову систему комах, від чого вони спочатку втрачають рухову активність, припиняють харчуватися, а потім гинуть впродовж доби.

Регулятор росту Гумат калію містить 70-75 \% гумусових кислот. Прискорює розвиток кореневої системи, підвищує врожайність, пригнічує вміст надлишкових нітратів. Цей препарат являє собою рідкі водорозчинні висококонцентровані екстракти на основі калієвих солей гумінових та фульвових кислот, отриманих з природної сировини - низинного торфу.

Схема чергування культур в сівозміні: 1. чорний пар, 2. пшениця озима, 3. буряки цукрові, 4. ярі зернові, 5. горох, 6. пшениця озима, 7. кукурудза на зерно і соя, 8. ярі зернові, 9. соняшник. Гній в сівозміні вносили по 30 т/га під чорний пар та під кукурудзу на зерно.

Об’єктами досліджень були сучасні гібриди кукурудзи: середньоранній гібрид Варта МВ та середньостиглий гібрид Кредит МВ. Густота рослин перед збиранням 60 тис. шт./га. Облікова площа ділянок $40 \mathrm{~m}^{2}$, повторність триразова. Технологія вирощування гібридів кукурудзи загальноприйнята для зони східного Лісостепу України за винятком варіантів, які вивчались.

Статистичний аналіз результатів експериментів здійснювали з використанням пакету комп'ютерних програм Statistica 6,0 (№ ліцензії BXXR502C631824NEN3), а також за допомогою методичних рекомендацій [6].

Грунти представлені потужним слабо вилугуваним чорноземом із зернистою структурою, товщина гумусного шару 75 см і більше.

За даними сектору агрохімії Інституту рослинництва ім. В. Я. Юр'єва НАAН грунт характеризується такими агрохімічними показниками: $\mathrm{pH}-$ 5,8; гідролітична кислотність - 3,29 мг-екв. на 100 г грунту; сума поглинутих основ - 37,4 мг-екв. на 100 г грунту. За 36 років існування сівозміни в грунті сформувалися такі запаси поживних речовин: на фоні без внесення добрив (сівозмінний фон) азот - 132 мг/кг, фосфор - 104 мг/кг та калій - 128 мг/кг і вміст гумусу (за Тюріним) - 5,2 \%, а на сівозмінному фоні з внесенням гною 30 т/га та 3 додатковим застосуванням повної норми мінеральних добрив - $\mathrm{N}_{60} \mathrm{P}_{60} \mathrm{~K}_{60}-$ азот - 140 мг/кг, фосфор - 177 мг/кг та калій -172 мг/кг і вміст гумусу (за Тюріним) $-5,6 \%$.

Погодні умови за 2009-2010 роки досліджень відзначились великою контрастністю, внаслідок чого змінювалась врожайність кукурудзи. Так, 2009 рік характеризувався посушливими погодними умовами за період вегетації кукурудзи - середньодобова температура повітря становила $18,9{ }^{\circ} \mathrm{C}$, що в межах середньобагаторічної $18,6^{\circ} \mathrm{C}$, а кількість опадів на 62,5 мм менша за середньобагаторічну, яка складала загалом за період 269,1 мм.

У 2010 році за період вегетації кукурудзи середньодобова температу- 
ра повітря на $2,6{ }^{\circ} \mathrm{C}$ перевищила середньобагаторічну $\left(18,6{ }^{\circ} \mathrm{C}\right)$, а кількість опадів становила 327,2 мм за середньобагаторічного показника 269,1 мм.

У 2009 році гідротермічний коефіцієнт складав 0,71 при середньобагаторічному значенні для культури 0,95 , що призвело до формування невисокого рівня врожайності. Гідротермічний коефіцієнт 2010 року був на рівні середньобагаторічного показника і складав 0,96. Впродовж вегетації кукурудзи в умовах даного року кількість опадів була не завжди продуктивною через зливові дощі з градом, що спричинило формування низької врожайності кукурудзи.

Результати досліджень. Кукурудза має широкий спектр патогенів та шкідників, які здатні викликати суттєве зниження польової схожості насіння. В умовах прохолодної та вологої весни проростки уражуються цілим комплексом збудників хвороб грибкової етіології з родів Pythium spp., Fusarium spp., Penicillium spp., Aspergillus spp., Alternaria spp. та інші. Крім цього, сходи пошкоджуються шведською мухою (Oscinella spp.), коваликами (Elateridae), чорнишами (Tenebrionidae spp.), озимою совкою (Agrotis segetum Schiff.), хлібною смугастою блішкою (Phyllotreta vittula R.).

Дослідженнями встановлено, що застосування комплексу препаратів фунгіциду Віал ТТ та інсектициду Табу сприяло підвищенню врожайності зерна кукурудзи за рахунок захисту рослин від ураження хворобами та шкідниками на ранніх стадіях розвитку культури. На даному варіанті отримано дружні сходи, ураження рослин збудниками грибкової етіології та ураження шкідниками (дротянками та озимою совкою) були мінімальними, а кількість рослин перед збиранням відповідала заданій густоті рослин перед збиранням. На варіанті без застосування препаратів - контролі - сходи з'являлись нерівномірно, рослини відставали у рості. Відмічено пошкоджені рослини хворобою грибковою етиологією, дротянкою та озимою совкою. Перед збиранням густота рослин не відповідала заданій густоті рослин (60 тис. шт./га).

Таки чином, застосування комплексу препаратів фунгіциду Віал ТТ та інсектициду Табу в середньому по гібридах на сівозмінному фоні підвищувало рівень врожайності на $0,45 \mathrm{~T} /$ га; на фоні внесення гною $30 \mathrm{~T} /$ га - на 0,32 т/га; повної дози добрив гній 30 т/га $+\mathrm{N}_{60} \mathrm{P}_{60} \mathrm{~K}_{60}-$ на 0,36 т/га (табл. 1). У середньому по досліду прибавка врожайності від застосування цих препаратів становила 0,42 т/га.

Найбільша прибавка врожайності від застосування препаратів відмічена у середньостиглого гібрида Кредит МВ на фоні обмеженого застосування добрив (гній $\left.30 \mathrm{~T} / г \mathrm{a}+\mathrm{N}_{30} \mathrm{P}_{30} \mathrm{~K}_{30}\right)-0,71 \mathrm{~T} / г \mathrm{r}$.

Найбільший рівень врожайності отримано при застосуванні комплексу агрозаходів: внесення повної дози добрив (гній 30 т/га $+\mathrm{N}_{60} \mathrm{P}_{60} \mathrm{~K}_{60}$ ) iз застосуванням препаратів Віал ТТ + Табу при густоті рослин 60 тис. шт./га - 6,60 т/га. Таким чином, відмічена позитивна реакція препаратів, що призвело до збільшення рівня врожайності гібридів кукурудзи. 
Таблиця 1

Урожайність гібридів кукурудзи залежно від фону живлення та протруєння насіннєвого матеріалу, т/га, 2009-2010 pp.*

\begin{tabular}{|c|c|c|c|c|c|}
\hline \multirow[b]{2}{*}{$\begin{array}{c}\text { Варіант обробки } \\
\text { насіння (В) }\end{array}$} & \multicolumn{4}{|c|}{ Фони живлення (А) } & \multirow[b]{2}{*}{ Середнє } \\
\hline & $\begin{array}{c}\text { без } \\
\text { добрив }\end{array}$ & $\begin{array}{c}\text { гній } \\
30 \text { т/га }\end{array}$ & $\begin{array}{c}\text { гній } \\
30 \mathrm{t} / г \mathrm{a}+ \\
\mathrm{N}_{30} \mathrm{P}_{30} \mathrm{~K}_{30}\end{array}$ & $\begin{array}{c}\text { гній } \\
30 \text { т/га }+ \\
\mathrm{N}_{60} \mathrm{P}_{60} \mathrm{~K}_{60} \\
\end{array}$ & \\
\hline \multicolumn{6}{|c|}{ Гібрид Варта МВ } \\
\hline Контроль без обробки & 2,98 & 2,52 & - & 2,57 & 2,69 \\
\hline Віал ТТ + Табу & 3,45 & 2,97 & - & 2,71 & 3,04 \\
\hline $\begin{array}{l}\text { Прибавка від протру- } \\
\text { ювання }\end{array}$ & $\mathbf{0 , 4 7}$ & $\mathbf{0 , 4 5}$ & - & 0,14 & 0,35 \\
\hline \multicolumn{6}{|c|}{ Гібрид Кредит МВ $^{1}$} \\
\hline Контроль без обробки & 4,18 & 5,74 & 5,79 & 6,02 & 5,43 \\
\hline Віал ТT + Табу & 4,61 & 5,92 & 6,50 & 6,60 & 5,91 \\
\hline $\begin{array}{l}\text { Прибавка від протру- } \\
\text { ювання }\end{array}$ & $\mathbf{0 , 4 3}$ & $\mathbf{0 , 1 8}$ & 0,71 & $\mathbf{0 , 5 8}$ & 0,48 \\
\hline
\end{tabular}

*Примітка. 1 - дані за 2009 рік, 2 - дані за 2010 рік.

Як правило, внесені добрива не забезпечують всього обсягу необхідних рослині елементів живлення і в дефіциті виявляються не враховані технологією мікроелементи. Гумати підвищують коефіцієнт засвоєння елементів живлення 3 грунту на 15-20\%. Це відбувається внаслідок активізації кореневої системи як у напрямку всисної здатності кореневих волосків, так i внаслідок активнішого переведення кореневими виділеннями нерозчинних елементів у засвійну форму. Прискорене всмоктування і транспортування рослиною елементів живлення відбувається через зростання проникності клітинних мембран. Зазначимо, що гумати $є$ природними хелатуючими речовинами і тому полегшують засвоєння елементів живлення, переводячи їх в органічну форму. Дія гуматів не обмежується лише поліпшенням надходження елементів живлення [7-10].

Гумати прискорюють синтез нуклеїнових кислот і білка, чим покращує стан посівів, активізує закладання генеративних органів у рослини. Саме тому, хоча гумати не можуть замінити ранньовесняного підживлення азотом, вони здатні зменшити негативний вплив від його відсутності, а при проведенні підживлення - доповнити його додатковим надходженням 3 грунту макро- і мікроелементів.

Обробка насіння гуматом калію зв'язує важкі метали та покращує структуру грунту. Витрати препарату становлять всього 200 г/т насіння, це від 0,79 грн./га для кукурудзи (норма висіву - 20 кг/га) до 5,54 грн./га - для сої (140 кг/га) та 7,92 грн. - для ячменю (200 кг/га), а в результаті зростання врожайності та багаторазове повернення кожної вкладеної гривні [11]. 
У 2009-2010 рр. також проведено дослідження з вивчення впливу торф'яного Гумату калію на рівень врожайності на прикладі середньораннього гібрида кукурудзи Варта МВ. Дослідженнями передбачалось три варіанти: контроль без обробки препаратом; обробка насіння $(0,25$ л/т); обробка насіння $(0,25$ л/т) + обприскування посіву у фазу $3-5$ листа $(0,4$ л/га).

Дані варіанти накладалися на фони мінерального живлення і встановлено, що найбільша прибавка врожайності відмічена на сівозмінному фоні із застосуванням гною 30 т/га на варіанті обробка насіння + обприскування посіву у фазу 3-5 листа - 0,58 т/га. На варіанті обробка насіння прибавка врожайності на даному фоні становила 0,26 т/га (табл. 2).

Таблиця 2

Урожайність гібрида кукурудзи Варта МВ залежно від фону живлення та обробки Гуматом калію, т/га, 2009-2010 pp.

\begin{tabular}{|c|c|c|c|c|}
\hline \multirow[b]{2}{*}{ Варіант (B) } & \multicolumn{3}{|c|}{ Фон живлення (А) } & \multirow[b]{2}{*}{ Середнє } \\
\hline & $\begin{array}{c}\text { без } \\
\text { добрив }\end{array}$ & $\begin{array}{c}\text { гній } \\
30 \text { т/га }\end{array}$ & $\begin{array}{l}\text { гній } 30 \text { т/га } \\
+\mathrm{N}_{60} \mathrm{P}_{60} \mathrm{~K}_{60}\end{array}$ & \\
\hline Контроль без обробки & 4,54 & 4,94 & 5,09 & 6,99 \\
\hline $\begin{array}{l}\text { Обробка насіннєвого мате- } \\
\text { ріалу }\end{array}$ & 4,68 & 5,21 & 5,51 & 7,45 \\
\hline $\begin{array}{l}\text { Обробка насіннєвого мате- } \\
\text { ріалу + обприскування } \\
\text { посіву у фазу 3-5 листа }\end{array}$ & 5,26 & 5,52 & 5,89 & 7,75 \\
\hline Прибавка від обробки насіння & 0,14 & 0,26 & 0,42 & 0,46 \\
\hline $\begin{array}{l}\text { Прибавка від обробки на- } \\
\text { сіння та посіву }\end{array}$ & $\mathbf{0 , 7 2}$ & $\mathbf{0 , 5 8}$ & $\mathbf{0 , 8 0}$ & 0,76 \\
\hline
\end{tabular}

У даному досліді найбільша прибавка врожайності зерна кукурудзи отримана на фоні внесення повної дози добрив (гній 30 т/га $+\mathrm{N}_{60} \mathrm{P}_{60} \mathrm{~K}_{60}$ ) + обробка насіння + обприскування посіву у фазу 3-5 листа $-0,80$ т/га. На варіанті обробка насіння $(0,25$ л/т) найбільша прибавка врожайності отримана на цьому ж фоні - 0,42 т/га.

Таким чином, відмічено позитивний ефект від застосування регулятору росту в середньому по фонах живлення із застосуванням препарату за обробки насіння та посіву кукурудзи у фазу 3-5 листків (у цей час починають закладатися бруньки майбутніх качанів, тому додаткове підживлення рослин дає добрий ефект) прибавка врожайності становила 0,76 т/га.

Висновки. Встановлено, що найбільший рівень врожайності отримано при застосуванні комплексу агрозаходів: внесення повної дози добрив (гній 30 т/га $+\mathrm{N}_{60} \mathrm{P}_{60} \mathrm{~K}_{60}$ ) із застосуванням препаратів Віал ТT + Табу при густоті рослин 60 тис. шт./га - 6,60 т/га. 
Відмічено, що найбільша прибавка врожайності від застосування препаратів Віал ТТ + Табу відмічена у середньостиглого гібрида Кредит МВ на фоні обмеженого застосування добрив (гній 30 т/га $+\mathrm{N}_{30} \mathrm{P}_{30} \mathrm{~K}_{30}$ ) $0,71 \mathrm{т} /$ га.

Дослідженнями $з$ вивчення впливу торф'яного Гумату калію на рівень врожайності зерна кукурудзи встановлено, що найбільша прибавка врожайності зерна кукурудзи отримана на фоні внесення повної дози добрив (гній 30 т/га $\left.+\mathrm{N}_{60} \mathrm{P}_{60} \mathrm{~K}_{60}\right)+$ обробка насіння + обприскування посіву у фазу 3-5 листа - 0,80 т/га. На варіанті обробка насіння $(0,25$ л/т) найбільша прибавка врожайності отримана на цьому ж фоні - 0,42 т/га.

\section{Список використаних джерел}

1. Зінченко О. І. Рослинництво : Підручник / О. І. Зінченко, В. Н. Салатенко, М. А. Білоножко. - К. : Аграрна освіта, 2001. - 249 с.

2. Кукуруза / [под редакцией А. В. Пухальского]. - К. : Гос. изд. с.-х. лит. Укр. ССР, 1955. - 263 с.

3. Кукуруза и ее улучшение [пер. с английского] / Е. Н. Волотова, Н. А. Емельяновой, О. В. Лисовской, М. П. Шикеданц. - М. : Изд. иностранной литературы, 1957. - 557 с. : ил.

4. Томашевский Д. М. Кукуруза / Д. М. Томашевский. - К. : Урожай, 1970. $337 \mathrm{c}$.

5. Ситнік В. П. Кукурудза - основа кормової бази високо продуктивного тваринництва / В. П. Ситнік // Вісник аграрної науки. - 2005. - № 8. С. 5-7.

6. Методические рекомендации по изучению сортовой агротехники в селекцентрах ; подгот. : П. П. Литун, В. М. Костромитин, Л. В. Бондаренко. М. : ВАСХНИЛ, 1984. - 32 с.

7. Шкаликов В. А. Защита растений от болезней / В. А. Шкаликов, О. О. Белошапкина, Д. Д. Букреев ; под ред. В. А. Шкаликова. - Изд. 2-е, перераб. и доп. - М. : Колос, 2003.

8. Пурлаур В. К. Обработка семян - важнейший фактор защиты растений / В. К. Пурлаур, Н. В. Михайленко ; под ред. Г. А. Романенко // Проблемы опустынивания и защита биологического разнообразия природохозяйственных комплексов аридных регионов России. - М. : Изд-во «Современные тетради», 2003.

9. Буга С. Ф. Роль протравителей семян / С. Ф. Буга, В. Н. Захаренко // Защита и карантин растений. - 2001. - №3. - С.18-25.

10. Адаптація «органічної» системи землеробства до природних і соціальних умов України / Е. Г. Дегодюк, С. Е. Дегодюк, С. З. Гуральчук, [та ін.] // Вісник Львівського національного аграрного університету. - 2011. - № 15 (2). - С. 238-246.

11. Гумати калію - вирішення проблем / Агромаркет. - 2011 р. - № 4 квітень. - С. 19-21. 
Обобщенные двухлетние данные (2009-2010 гг.) исследований по изучению реакции гибридов кукурузы на применение регулятора роста и средств защиты растений показали, что наибольшая прибавка урожайности от обработки семян фунгицидом Виал ТТ и инсектицидом Табу отмечена у среднеспелого гибрида Кредит МВ на фоне ограниченного применения удобрений (перегной 30 т/га $+\mathrm{N}_{30} \mathrm{P}_{30} \mathrm{~K}_{30}$ ) - 0,71 т/га. В опыте по изучению реакции среднераннего гибрида Варта МВ на применение регулятора роста растений Гумата калия наибольшая прибавка урожайности зерна получена на фоне внесения полной дозы удобрений (перегной 30 т/га $\left.+\mathrm{N}_{60} \mathrm{P}_{60} \mathrm{~K}_{60}\right)+$ обработка семян + опрыскивание посева в фазу 3-5 листа $-0,80$ т/га.

Generalized 2-year data (2009-2010) researches on the studies of the reaction of corn hybrids on application of the growth regulator and means of plant protection have shown, that the greatest increase of the seed processing productivity by Vial TT fungicides and Taboo insecticides is marked at hybrid of Credit MV average ripeness on the background of the limited application of fertilizers (humus $30 \mathrm{t} / \mathrm{ha}+\mathrm{N}_{30} \mathrm{P}_{30} \mathrm{~K}_{30}$ ) $-0.71 \mathrm{t} / \mathrm{ha}$. Under the experience on the reaction studies of the Varta MV hybrid of early average ripeness on application of the growth regulator of the Gumata of potassium plants the greatest increase of productivity of grain is received on the background of the full dose of fertilizers (humus $30 \mathrm{t} / \mathrm{ha}+\mathrm{N}_{60} \mathrm{P}_{60} \mathrm{~K}_{60}$ ) + processing of the seeds + spraying of the crop in a phase 3-5 sheets -0.80 t/ha. 